\title{
UNINTENDED PREGNANCY: KNOWLEDGE AND ATTITUDE OF YOUNG ADOLESCENT
}

\author{
Nurina Sari Supriatna ${ }^{1}$, Restuning Widiasih ${ }^{1}$, Mira Trisyani $^{1}$ \\ Faculty of Nursing, Universitas Padjadjaran \\ Corresponding email: restuning.widiasih@unpad.ac.id
}

\begin{abstract}
Unintended Pregnancy (KTD) is one of the adolescent health problems as the number has increased annually and impacted to adolescent, physically and psychologically. Many studies assessed adolescents' knowledge of KTD in middle and late adolescent groups. However, the study that assesses early adolescents (12-15 years) about KTD are limited. The aim of this study was to examine early adolescent knowledge and attitudes about KTD. This research was quantitative descriptive research. This study involved 373 female students in Jatinangor, West Java. Data were collected by a questionnaire that assessed adolescents' knowledge and attitude of KTD and were analyzed using statistical analysis. Results showed that teenagers' knowledge of KTD was good, and their attitudes towards KTD showed a conative attitude, adolescents have carried out behavior that might cause of KTD. Early adolescents have good knowledge about KTD, however, they knew risky behavior may happen to them. It is necessary to increase early adolescents' awareness of KTD.
\end{abstract}

Keywords: adolescence, attitude, knowledge, unintended pregnancy.

\section{INTRODUCTION}

Unintended Pregnancy (KTD) is a pregnancy that is unplanned or unwanted may result from rape, incest, or sex before marriage (Amalia, 2017). Citrawathi (2013) said unintended pregnancies occur because of teenagers' limited health literacy and unpreparedness related to reproduction and sexuality health. Data on the Health Survey in Indonesia of 10.830 unmarried boys and 8,481 girls from 33 provinces in Indonesia found that $1 \%$ of women and $6 \%$ of men had premarital sex, and $11 \%$ of them experienced unintended pregnancies (Fitrotun, 2012). Unintended pregnancy threatens adolescents' health.

KTD in adolescent stimulate various problems including social problems such as negative stigma from community, dropped out of school, and a new role as a mother (Sarwono, 2003; Susanti, 2015). The impact of KTD on teenage pregnancies include obstructed labor (congestion), prolonged labor, and long-term complications (Realita, 2016). The pregnancy also has risks to the baby including injury, and low birth weight, as a result, the baby's life survival may very low (Waspodo, 2005; Reality, 2016). To deal with teenagers' health and social problems, the Ministry of Health of the Republic of Indonesia has developed a youth health program, the Youth Care Health Service (PKPR). In 2013, the Directorate of Child Health Development announced that there are 3,086 PKPR from 406 districts in Indonesia (Kemenkes, 2015). PKPR provides information to adolescents related to physical and psychological changes, problems that may arise, methods to deal with them, strategies to maintain 
Nurina Sari Supriatna : Unintended Pregnancy: Knowledge and Attitude of Young Adolescent

health, healthy relationships between male and female, family planning, STIs, and HIV / AIDS (Kemenkes, 2015).

The Jatinangor Public Health Center is a PHC in West Java Indonesia that has the PKPR program and provides 2 services: the first is inside building services such as a youth clinic and training for health school cadres. Second is the services outside the building such as health services at schools, counseling and health education. Counseling topic focused on problems that exist in an adolescent at Jatinangor sub-district including unintended pregnancy. Although the PKPR program is established in the PHC of Jatinangor, in fact, teenage reproductive health problems and KTD has increased annually. In 2016, there were 346 pregnant women age range of 10-19 years in the PHC of Jatinangor These young women are in the category of adolescents. The data showed that adolescent who experience KTD was at year VIII or junior high school students. The number of KTD cases has increased in Jatinangor sub-district, even though the PHC already had PKPR programs and school around the PHC received routine counseling. Many studies assessed adolescents' knowledge of KTD in middle and late adolescent groups. However, the study that assesses early adolescents (12-15 years) about KTD are limited. The aim of this study was to examine early adolescent knowledge and attitudes about KTD

\section{METHODS}

The research design in this study was descriptive quantitative, using 2 variables which are the level of knowledge and attitudes toward unwanted pregnancy. The population in this study were students of year VII and VIII of the Jatinagor Junior High School. The characteristic of the respondents was female and aged 12-15 years. The respondents were chosen using total sampling technique. 373 female students involved in this study. The research instrument assessed respondents' knowledge of KTD and reproductive health system, there were 6 indicators of questions including puberty in women, organs, and functions of female genitalia, menstruation, pregnancy, unwanted pregnancy and pregnancy under the age of 20 years. For attitudes, there were 3 indicators, including adolescent sexual health education, PKPR, and unwanted pregnancy. The instrument has been tested for validity and reliability with results, the validity test result for knowledge variable was $0.303-0.750$ and reliability 0.732 . The validity for attitudes questions were $0.446-0.763$ and reliability 0.743 . Data collection was carried out in July-August 2018. Ethics was obtained by researchers from the Universitas Padjdjaran ethics committee with number: 923 / UN6.KEP / EC / 2018. 


\section{RESULTS}

\section{Characteristic of respondents}

Table 1. Characteristic of respondents $(n=373)$

\begin{tabular}{lllllll}
\hline \multirow{2}{*}{ Characteristic } & \multicolumn{2}{c}{ Year VII } & \multicolumn{2}{c}{ Year VIII } & \multicolumn{2}{c}{ Total } \\
\cline { 2 - 7 } & f & \% & f & \% & f & \% \\
\hline Ages & & & & & & \\
$\quad$ Less than 12 years & 4 & 2.19 & - & - & 4 & 1.07 \\
$\quad$ More than 12 years & 179 & 97.81 & 190 & 100 & 369 & 98.93 \\
\hline Information sources & & & & & & \\
$\quad$ Parents & 74 & 40.44 & 102 & 53.68 & 176 & 47.18 \\
Health workers & 47 & 25.68 & 50 & 26.32 & 97 & 26.01 \\
Teacher & 15 & 8.20 & 10 & 5.26 & 25 & 6.7 \\
$\quad$ Media: book and & 5 & 2.73 & 20 & 10.53 & 25 & 6.7 \\
$\quad$ internet & & & & & & \\
$\quad$ Friends & 10 & 5.46 & 8 & 4.21 & 18 & 4.83 \\
$\quad$ Neighbour & 32 & 17.49 & - & - & 32 & 8.58 \\
\hline Friends with KTD & 15 & 8.20 & 10 & 5.25 & 25 & 6.7 \\
\hline
\end{tabular}

Table 1 describes that the majority of respondents were over 12 years old. They received information KTD mostly from parents, 176 respondents (47.18\%). 25 respondents (6.7\%) had friends or relatives who experienced KTD.

\section{Knowledge of Unintended Pregnancy}

Table 2. Respondents' Knowledge of Unintended Pregnancy ( $n=373)$.

\begin{tabular}{lcccc}
\hline \multicolumn{1}{c}{ Knowledge Components } & $\begin{array}{c}\mathbf{f} \\
\text { Know }\end{array}$ & $\boldsymbol{\%}$ & $\begin{array}{c}\mathbf{f} \\
\text { Do not } \\
\text { Know }\end{array}$ & \% \\
\hline Women Puberty & 366 & 98.12 & 7 & 1.9 \\
Anatomy and Physiology of & 295 & 79.09 & 78 & 20.9 \\
reproductive organ & & & & \\
Menstruation & 366 & 98.12 & 7 & 1.9 \\
Pregnancy & 290 & 77.75 & 83 & 22.25 \\
Unintended Pregnancy & 283 & 75.87 & 90 & 24.12 \\
Labour & 348 & 93.3 & 25 & 6.7 \\
\hline
\end{tabular}

Table 2 shows that adolescents have good knowledge in the 6 components of KTD knowledge with $87 \%$ of respondents answering questions correctly. The lowest score was about respondent's understanding of unintended pregnancies (76\%). 304 respondents had a good level of knowledge (81.5\%). classes VII and VIII have a level of knowledge with a similar average, but in class VII there are 7 respondents $(1.9 \%)$ with low-level knowledge. 


\section{Attitude}

Table 3. Adolescents' attitude of unintended pregnancy (n: 373).

\begin{tabular}{lcccccc}
\hline \multirow{2}{*}{ Attitude } & \multicolumn{2}{c}{ VII } & \multicolumn{2}{c}{ VIII } & \multicolumn{2}{c}{ Total } \\
\cline { 2 - 7 } & f & \% & F & \% & f & \% \\
\hline Favorable & 35 & 19.1 & 65 & 34.2 & 100 & 26.8 \\
& & & & & & \\
Unfavorable & 148 & 80.9 & 125 & 65.8 & 273 & 73.2 \\
\hline
\end{tabular}

Table 3 shows that the majority of respondents who did not support meant that respondents had a counter attitude towards KTD, 273 respondents (73\%), and 27\% KTD could be accepted and might occur at their age.

\section{DISCUSSION}

The study showed that most respondents had a good level of knowledge about KTD both respondents year VII and year VIII. However, there were several respondents in year VII who had a lack of knowledge $(n=7)$. A good level of knowledge may be influenced by several factors, including age, Irawan (2016) said that the age factor influences understanding and mindset of a person. Respondents who have a lack of knowledge are respondents were students at year VII (ages 11-12 years), it is possible because, in Indonesia, the student receives information about reproductive health at year VIII. The student in year VII may obtain reproductive health information from other information sources such as movie, or the internet.

This finding in opposite Ulfah's (2016) study, she found that students' knowledge was lacking, and teachers played a role in increasing the knowledge of school-age children especially related reproductive health. The teacher also provides information for other school staffs about health issues in adolescents, and the teacher is a listener of students' problems every day. There are other factors that influence the level of knowledge of adolescents. Research Reality (2016) found that there are several factors that influence the knowledge of KTD, for the early adolescent did not get any specific related to reproductive health, they are no specific themes or subjects that discuss reproductive health, except biology subject.

Respondents were 11-13 years old, means they are in puberty period, they have menstruation. Menstruation in adolescent usually occurs when the age of 10-16 years, it depends on several factors, including women's health, nutritional status, and weight (Lestari, 2013). Respondents had experienced organ maturity and also obtained information about reproductive health and its effects, including KTD. The source of information should be trusted so that adolescents do not get the wrong information. The majority of respondents received information about reproductive health from parents. 
Parents are very important in providing reproductive health information as KTD prevention. Sujarwati' (2014) study found that parents play an important role in sexual education.

For the attitude variable, the majority of respondents had not to support KTD in adolescents. Attitude is part of the internal factors that influence sexual behavior. There are two factors which are internal and external factors. Internal factors include the level of knowledge, education, attitude, and lifestyle. The external factors which consist of friends, mother, father, siblings, relatives, teachers, health workers, and religious leaders. The results of this study are in line with Umaroh's (2015) research. She examined knowledge and attitude too. Results found that respondents have a good level of knowledge, but have a negative attitude. So even though teenagers have a good level of knowledge, but they risk of KTD, as they do not have a good attitude, teenagers have a risk to engage in sexual behavior. The attitude towards premarital sexual relations is measured based on the attitude components proposed by Azwar (2017), which consists of cognitive, affective, and behavioral components (conative). According to the attitude components, this study found the largest average value is the conative component, and the smallest is the effective aspect. Affective aspects are feelings that involve emotional aspects (Ekawati, 2017). The effective component affected the behavior component premarital sexual relations among adolescents (Presmawari, 2017). Presmawari (2017) said the affective attitude was a component of love from adolescents. Psychologically, love is an emotional human behavior whose form of an individual's emotional response or reaction to certain stimuli (Faiz, 2002; Presmawari, 2017). One of the factors that would encourage adolescents to have premarital sexual intercourse is because teenagers have a perception that sexual relations become a way to express love, so individuals are willing to have sexual relations with partners before marriage (Setyawan, 2004; Presmawari, 2017). Having sex before marriage is not the Indonesian culture.

\section{CONCLUSION}

Based on data analysis it was found that student knowledge varied, there were students who were well-informed, while several of them were lack of knowledge. The level of knowledge influenced by several factors including age, information sources, and the role of social support such as health workers, teachers, friends, and parents. The attitude of female students in Jatinangor was dominated by non-supportive attitudes towards KTD, which meant that they considered that KTD was not acceptable behavior in early adolescents like them. This research is the initial information about the level of knowledge and attitudes of Jatinangor students about KTD, there is no data that examines more deeply the role of health services, teachers, friends and parents in preventing KTD. It is necessary to provide balanced reproductive health education for each component. Developing appropriate, innovative, and 
Nurina Sari Supriatna : Unintended Pregnancy: Knowledge and Attitude of Young Adolescent

creative learning programs regarding the reproduction health by involving parents, and teachers would be useful in preventing KTD.

\section{REFERENCES}

Amalia, Happy Elisa., Muhammad Azina. (2017). Kehamilan tidak diinginkan pada remaja. Higeia : journal of public health research and development, 1(1).

Arsani, Ni Luh Kadek Alit., Ni Nyoman Mestri Agustini., I Ketut Indra Purnomo. Peranan Program PKPR (Pekayanan Kesehatan Peduli Remaja) Terhadap Kesehatan Reproduksi Remaja di Kecamatan Buleleng. Jurnal Ilmu Sosial dan Humaniora, 2(1), 129137.

Azwar, Dr. Saiffudin. (2013). Sikap Manusia: Teori dan Pengukurannya (ke-2). Pustaka PelajarYogyakarta.

Citrawathi, Desak Made. (2013). Faktor Determinan Pelaksanaan Pendidikan Kesehatan, (2), 316322.

Dewi, Ni Luh Putu Rustiari., \& IB Wirakusuma. (2017). Pengetahuan dan Perilaku Seksual Pranikah pada Remaja SMA di Wilayah Kerja Puskesmas Tampaksiring I, L.E-Jurnal Al Medika, VI(10), $50-54$.

Ekawati., Kiki Indriyanti. (2017). Sikap Remaja Putri Terhadap Pernikahan Dini Di Dusun Wonotoro Desa Jatiayu Kecamatan Karangmojo Kabupaten Gunungkidul. 4(1), 35-41.

Fitrotun, Eni., Imbarwati dan Dewi Elliana. (2012). Hubungan Pengetahuan Remaja Putri Tentang Kehamilan Tidak Diinginkan (KTD) Dengan Sikap Terhadap Aborsi Di Kelurahan Ngemplak Simongan Kota Semarang.

Irawan, Erna. (2016). Gambaran Pengetahuan Remaja Tentang Kesehatan Reproduksi Di Desa Kertajaya. Jurnal Ilmu Keperawatan, 4(1), 26-31.

Karniyanti, Ni Kadek., Made Diah Lestari. (2018). Peran Kontrol Diri Dan Asertivitas Pada Sikap Terhadap Perilaku Seksual Pranikah Pada Remaja Akhir Perempuan Di Bangli. Jurnal Psikologi Udayana, 5(1), 72-85.

Kemenkes RI. (2015). Pedoman Pelayanan Kesehatan Reproduksi Terpadu di Tingkat Pelayanan Kesehatan Dasar.

Lestari, N. M. S. D. (2013). Pengaruh dismenorea pada remaja. Seminar Nasional $\quad$ FMIPA UNDIKSHA III, 323-329. Retrieved from ejournal.undiksha.ac.id/index.php/semnasmipa/article/download

Ni Luh Kadek Alit Arsani, Ni Nyoman Mestri Agustini, I. K. I. P. (2013). Peranan Program PKPR Terhadap Kesehatan Reproduksi Remaja Di Kecamatan Buleleng. Jurnal Ilmu Sosial Dan Humaniora, 2(1), 129-137.

Realita, Friska., Alfiah RAhmawati. (2016). Pengetahuan Remaja Putri Tentang Kehamilan Tidak Diinginkan. Jurnal Kebidanan, 8(2), 127-224. Reproduksi dengan Perilaku Seks Pranikah pada Remaja Usia (15-17 tahun) 
Nurina Sari Supriatna : Unintended Pregnancy: Knowledge and Attitude of Young Adolescent

Susanti, Lina Wahyu., Siti Farida. (2015). Gambaran Tingkat Pengetahuan Remaja Perilaku Seks Bebas di SMA I Teras Boyolali. INFOKES, 5(2),

Ulfah, Zakia., Atik Mawarni., Djoko Nugroho., Yudhy Dharmawan. (2016). Hubungan Pengetahuan Dan Sikap Dengan Praktik Kesehatan Reproduksi Siswa Di SMK "X" Kabupaten Kebumen Triwulan I Tahun 2016. Jurnal Kesehatan Mayarakat, 4(4), 265274.

Umaroh, Ayu Khoirotul., Yuli Kusumawati., Heru Subaris Kasjono. Hubungan Antara Faktor Internal dan Eksternal Dengan Perilaku Seksual Pranikah Remaja di Indonesia. Jurnal Kesehatan Masyarakat Andalas, X(1), 65-75. 